HOW, a Colombian Journal of Teachers of English. No. 7, (pp. 116-118). (ISSN: 0120-5927). 2000.

APA citation style: Benavides B., Jorge E. (2000). CALL, Self-access and Autonomous Learning. HOW, a Colombian Journal of Teachers of English) (7), 116-118.

\title{
CALL, Self-access, and Autonomous Learning
}

\author{
Jorge E. Benavides B.' (joelbebu@gmail.com) \\ Departamento de Lingüística e Idiomas \\ Universidad de Nariño, San Juan de Pasto, Colombia
}

The idea of autonomous learning through a process of self-access learning is a very powerful one since CALL (Computer-Assisted Language Learning) can provide environments which could cope with a large variety of learning possibilities and learning styles. The autonomous computer user is free to choose his own course, topics, and work at his own pace. However, in this approach, high motivation may not necessarily mean learning efficiently. The student may not be very good at selecting his own learning strategy especially at initial stages. This problem could be alleviated if the introduction of learning autonomy, through self-access learning, is done as a process where the learner is being trained to progressively go from an externally-directed-learning approach to a self-directed learning approach, (Aparicio et al, 1995).

One of the solutions for achieving autonomous learning could be to use a self-access system where the students can choose tasks and activities without these necessarily being assigned by the teacher. This would lead to a more flexible way of learning, in which learning contexts have to be made appropriate to the students' individual needs (provided there are the facilities, resources, materials and guidance available and organized in a resource center).

Thus, the learners will be involved in meaningful tasks, problem solving, decision making, etc. thereby promoting their responsibility for their own learning. This process by no means underestimates the role of the teacher. In the end, the ideal learner would be the one who at any stage in the process of education is less dependent on the teacher to sort out his own learning challenges. Similarly, the ideal teacher would be the one who after his gradual and progressive guidance can see the learner at a later stage of his educational process as an independent, responsible, and self-confident learner.

We can see a self-access system in language learning to be more associated with the Vygotskyan view of learning rather than with the behavioristic approach to teaching. In the behaviorist operant-conditioning

\footnotetext{
${ }^{i}$ Jorge E. Benavides B. is an Associate professor and researcher on foreign language learning and the pedagogical use of new information and communication technologies and the Internet (Research Group) at Universidad de Nariño -San Juan de Pasto, Colombia.
} 
HOW, a Colombian Journal of Teachers of English. No. 7, (pp. 116-118). (ISSN: 0120-5927). 2000.

approach teaching is central, whereas for the constructivists and Vygotskyans learning is central, and teaching is only a vehicle for creating the conditions and contents for the learners, in what Jones \& Mercer, (1993) call 'self-motivated, self-directed learning'. Thus, directed learning can be considered harmful in that it is not necessarily based on the learner's understanding.

McDonough, (1993) gives a good example of how self-access work can be implemented in reading which can also be implemented in CALL. Teachers do the planning and design, adaptation and even production of materials to be placed in the classroom as part of a 'reading laboratory' resource center. Stoller, (1984), (cited in Mcdonough, 1993) outlines the features of such a laboratory: it should,

- Accommodate a wide variety of student reading levels

- Have a large variety of reading selections at each reading level

- Have a selection of high interest topics appropriate to the learners

- Allow for systematic progression from one level to another

- Allow students to progress at their own pace

- Include a self-correction system

- Include charts and graphs for easy record keeping

- Include a placement test for accurate level assignment

- Include exercises that require students to practice a variety of reading skills and strategies.

We need to take into account that self-access does not necessarily mean that the learner, especially at the beginning stages has to be let alone facing the computer. Again, this has been one of the strongest misconceptions in the traditional picture of CALL, where computer use implies the substitution of the teacher by the computer, that is, a complete self-access use with the machine without considering contextual, affective, social and developmental factors. In a self-access situation, CALL should be presented as a flexible and supplementary classroom aid, at an early stage in the process of reaching autonomous learning and learning independence. Such stage has to be planned and structured carefully without disregarding the teacher's role.

\section{CALL in the language curriculum}

At international level we know that many English programs -as well as Native language programs- have introduced some form of CALL in their curricula. This implies that there has to be some kind of organization, planning and structure of this new academic element. Planning, course design, materials design, testing, evaluation; assessment as well as a good dose of computer literacy have to be taken into account for this type of implementation.

There is a world-wide trend to initiate the first steps into what is called technologically-based aids to learning, and therefore we can suggest a pedagogically oriented CALL, that is, a variety of innovative language-learning activities. We can get to know new tools and new environments for learning, and consequently new language learning strategies. This has to lead to changes in terms of learner 
HOW, a Colombian Journal of Teachers of English. No. 7, (pp. 116-118). (ISSN: 0120-5927). 2000.

independence, since CALL can start as part of classroom work. Then CALL could be well found in language learning centers or resource centers. In a CALL context we can also combine teaching with research on learning in this new field keeping track of what learners do in order to get to know more about the learning process.

We need to understand in what ways technology-based materials, can facilitate language learning. And this is a task that might be undertaken by teachers, administrators and students since most of the reports on CALL are basically anecdotal and do not have an empirical basis. There is wide range of interdisciplinary research in this area and we can take advantage of the research experiences on second and foreign language acquisition and learning in the 60's and 70's in order to make a more consistent and profitable work.

\section{CALL and Autonomous Learning}

One of the ways of enriching and supporting the language curriculum and promoting independent learning is through the appropriate use of Information technology represented in CALL as in or out of classroom activities. However, it is important to consider that technology-based learning, whether it is integrated into the language curriculum or used as a self-access system is not to be taken as a panacea or even worse as a complete substitution of classroom instruction. It has to start as supplementary work of what is done in the classroom, and this has to be especially considered during the first stages of CALL introduction into the language curriculum.

The concerns and questions to be asked before thinking of introducing new technology in the language curriculum are, among others:

- How and to what extent can Information technology be introduced into the language curriculum?

- To what extent can it be introduced to support educational goals?

- What is the most appropriate technology?

- How is the new technology going to be used?

- How effective is it for language learning?

- What is the role and relationship of pedagogy in terms of the good use of technology?

\section{Appropriate technology and effective learning}

Another area of concern not only for teachers but for curriculum developers, course designers and course evaluators is the effectiveness of CALL. So we can start asking ourselves chow and to what extent can information technology in the form of CALL contribute to enriching the language curriculum and therefore enhancing and improving language learning? The answer to this question will have to be dealt in the process of before, and during the process of introduction of CALL.

In general terms we can say that and appropriate integration of CALL into the language curriculum would be able to achieve the following goals: 
HOW, a Colombian Journal of Teachers of English. No. 7, (pp. 116-118). (ISSN: 0120-5927). 2000.

- $\quad$ Provide the means for achieving some degree of computer literacy for teachers and students

- $\quad$ Familiarize teachers and students with the demands of IT in language learning as part of the education scheme

- $\quad$ Give ownership to teachers and students to the use of computers for language learning.

- $\quad$ Provide teachers with different modes for language teaching.

- $\quad$ Provide students with different modes for language learning.

- $\quad$ Provide teachers with the context for doing research in language learning through CALL.

- Introduce the concept of pedagogically oriented technology

In sum, the new information technology in second and foreign language learning has been striving for configuring its own methodological framework taking what is available in the field. It seems quite understandable that something that emerges as a product of modern technology tries to fit into existing models for learning. A self-access system seems to be the most appropriate way to make CALL grow in order to provide that appealing and challenging characteristic in students, we as teachers all desire: learning autonomy.

\section{REFERENCES}

Aparicio, B., Benavides B., Jorge. E., Cárdenas, L., Ochoa, J., Zuluaga, O., \& Ospina, C. (1995). Learning to Teach. Teaching to learn. COFE Project Document No. 5. Thames Valley University. London, UK.

Jones, A. \& N. Mercer. (1993). Theories of Learning and Information Technology, In P. Crimshaw. (Ed.) Language classrooms and computers. London: Routledge.

McDonough, J. \& Shaw, C. (1993). Materials and Methods in ELT: A teachers Guide. Cambridge, Massachusetts: Blackwell.

Stoller, A. (1984). Developing reading skills through CALL. In McDonough, J. \& Shaw, C. (1993) Materials and Methods in ELT: A teachers Guide. Cambridge, Massachusetts: Blackwell 